Reprod. Nutr. Dévelop., 1983, 23 (2 A), 245-257.

\title{
Plasma insulin and insulin kinetics in growing sheep. Influence of age and diet
}

\author{
J. GRIZARD, M. SZCZYGIEL (*)
}

Laboratoire d'Etude du Métabolisme azoté, I.N.R.A. Theix, Saint-Genès-Champane/le, 63110 Beaumont, France.

(*) Institute of Animal Physiology, Veterinary Faculty, Agricultural Academy in Warsaw, Poland.

\begin{abstract}
Summary. This study was carried out to clarify the nutritional control of insulin metabolism in growing sheep fed a control or an experimental diet low in crude protein and high in propionic acid used as a feed additive. Daily variations in blood insulin and the disappearance from the circulation of unlabelled injected insulin were investigated. These data were used to calculate the metabolic clearance rate of insulin and insulin secretion.

At $23 \mathrm{~kg}$ of body weight (BW), blood insulin showed an increase in the control group at 10 a.m. (i.e. $2 \mathrm{~h}$ after feeding) and a large peak in the experimental group at $3 \mathrm{p} . \mathrm{m}$. At 33-kg BW, blood insulin in both groups showed a peak at $10 \mathrm{a} . \mathrm{m}$. and a moderate increase at 3 p.m. Mean plasma insulin throughout the day (except at 3 p.m.) rose with increasing BW. It was lower in the experimental than in the control group.

Injected insulin disappeared rapidly from the circulation; its half-life was constant $(13 \mathrm{~min})$. In both groups, the insulin level along the disappearance curve was higher at $33-\mathrm{kg}$ BW than at $23-\mathrm{kg}$ BW, and insulin metabolic clearance rate decreased. Except at $3 \mathrm{p} . \mathrm{m}$., the mean insulin secretion rate over the day was lower in the control group at 33$\mathrm{kg} \mathrm{BW}$ than at $23-\mathrm{kg}$ BW. Feeding the experimental diet increased the insulin level along the disappearance curve. In young animals, it decreased insulin metabolic clearance rate and diminished mean insulin secretion rate over the day, except at $3 \mathrm{p} . \mathrm{m}$. when the insulin secretion rate increased. In old animals, the experimental diet did not significantly change the kinetic parameters of insulin metabolism.
\end{abstract}

\section{Introduction.}

The progressive alteration of the ruminant forestomach that allows herbage cellulose to be digested results in major changes in the absorbed metabolites. Little glucose is directly derived from dietary carbohydrate since it is converted into volatile fatty acids as a result of microbial fermentation in the rumen. The major site of glucose supply is the liver. Much dietary protein is degraded in the rumen. Thus, the amino acids supplied by the digestive tract are derived from microbial protein. The processes of digestion and absorption last longer in ruminants than in non-ruminants. These animal characteristics correlate with the fact that the secretion and degradation of insulin are probably lower in ruminants than in non-ruminants (Trenkle, 1971 ; Brockman and Bergman, 1975). However, 
in ruminants as in non-ruminants, blood insulin varies in direct relation to feeding. Vagal reflex, intestinal hormones and absorbed metabolites (short-chain fatty acids, glucose, amino acids) seem to be involved in the regulation of insulin secretion in ruminants (Bassett, 1975 ; Trenkle, 1978).

Taking these observations into account, the aim of the present work was to clarify the nutritional control of insulin metabolism in growing sheep fed a control or an experimental diet low in crude protein and high in free propionic acid used as a feed additive. We investigated daily variations in blood insulin and the disappearance of insulin from the circulation. These data were used to calculate the distribution volume in the body, metabolic clearance rate and the secretion rate of the hormone. Part of this work was previously reported in an abstract (Grizard and Szczygiel, 1980).

\section{Material and methods.}

Animal and diets. - - We used the male progeny of Romanov $\times$ Limousin sheep born the second week of November and having an average starting weight of $18 \mathrm{~kg}$. They were housed in individual stalls under natural lighting conditions (light from about 8 a.m. to 6 p.m.) in a room maintained at $20-22{ }^{\circ} \mathrm{C}$ and were divided into two groups, one fed a control diet and the other fed an experimental diet. The control diet was similar to the usual diets for growing sheep (table 1) (Jarrige, Journet and Vérité, 1978). The experimental diet was also in the range of normal sheep nutrition. There were two major differences between the diets. First, because the experimental diet did not contain high-protein ingredients (soya-bean meal and linseed oil meal), it had less crude protein than the control diet $(12.6 \%$ vs $14.7 \%)$. Secondly, free propionic acid, higher in the experimental than in the control diet, was used as a feed additive in the maize. The animals were given a complete ration at 8:30 a.m. Water was provided ad libitum. The trend of changes in the rate of feed intake was similar in both groups throughout the day (fig. 1).

\section{TABLE 1}

Diet composition

(\% of dry matter)

Ingredients

Control diet $\left(^{*}\right)$ Experimental diet

Dehydrated alfalfa
Urea
Soya-bean meal (50\% crude protein)
Linseed oil meal
Maïze $\left\{\begin{array}{l}\text { supplemented with propionic acid } \\ \text { unsupplemented with propionic acid }\end{array}\right.$
Propionic acid
Molasses
Vitamin-minerals

$\left(^{*}\right)$ In the control diet, urea, soya-bean meal, linseed oil meal and molasses were supplied by a standard concentrate that also contained maize, unsupplemented with propionic acid, and $40 \%$ of vitamin-minerals. 
Due to small decreases in the voluntary intake of such ingredients as dehydrated alfalfa and maize (supplemented with propionic acid), the true nutritional status of the animals was slightly different than the expected nutritional status. For example, in the control group, nitrogen intake was slightly lower than the estimated nitrogen requirements for $23-\mathrm{kg} \mathrm{BW}$, whereas it was adequate at 33-kg BW (table 2) (Jarrige, Journet and Vérité, 1978). However, at any BW of the control animals, gain and feed efficiency were acceptable. Daily protein intake was significantly lower in the experimental than in the control group (- $-35 \%$ and $-23 \%$ at 23 and $33 \mathrm{~kg}$ of liveweight, respectively). In addition, daily intake of dry matter was reduced $(-21 \%)$ in the experimental group at 23-kg BW.

Daily variations in plasma insulin and disappearance of injected insulin from the circulation. - The sheep were measured twice i.e. at 23 and 33-kg BW, respectively. A polyethylene catheter (length : $120 \mathrm{~mm}$, i.d. : $1.1 \mathrm{~mm}$, o.d. : 1.6 $\mathrm{mm}$; intranule, Vygon, France) was inserted into the jugular vein and sutured to the skin. It remained in situ for 4 days. The day after catheter insertion, nine blood samples were taken over a 24-hour period to measure daily variations in plasma insulin and blood metabolites. From 10 a.m. to 4 p.m. on the second or third day after catheter insertion, unlabelled porcine monocomponent insulin (MC S837261, $26.8 \mathrm{IU} / \mathrm{mg}$ ) was dissolved in saline $10.9 \% \mathrm{NaCl}, \mathrm{W} / \mathrm{V}$ ) and then rapidly injected intravenously via the catheter in amounts varying from 12 to $17 \mu \mathrm{g} / \mathrm{kg}$ of BW. The catheter was rinsed several times with saline. To measure the disappearance of injected insulin from the circulation, one blood sample was taken before injection and 6 blood samples were collected over the 2-hour period following injection. All blood samples were heparinized and put into an ice-bath until the plasma could be separated by centrifugation. The plasma was stored at $-15^{\circ} \mathrm{C}$.

This technique allowed us to assess the in vivo responsiveness of sheep tissue to ovine insulin. Indeed, the biological activity of porcine and ovine insulin

TABLE 2

Characteristics of the animals used over two blood sampling periods

\begin{tabular}{|c|c|c|c|c|c|}
\hline \multirow{2}{*}{ Group } & \multicolumn{2}{|c|}{ First period } & \multicolumn{2}{|c|}{ Second period } & \multirow{2}{*}{$\begin{array}{l}\text { Mean coeffi- } \\
\text { cient of varia- } \\
\text { tion }(\%)\end{array}$} \\
\hline & Control & Experimental & Control & Experimental & \\
\hline $\begin{array}{l}\text { Number of animals } \\
\text { Average age (weeks) }\end{array}$ & 6 & $\begin{array}{c}6 \\
11.5\end{array}$ & $\begin{array}{c}6 \\
15.5\end{array}$ & $\begin{array}{c}6 \\
18.0\end{array}$ & \\
\hline $\begin{array}{l}\text { Liveweight on first blood } \\
\text { sampling day }(\mathrm{kg})\end{array}$ & 24.4 & 22.2 & $32.8\left(^{b}\right)$ & $32.4(\mathrm{~b})$ & 8.6 \\
\hline $\begin{array}{l}\text { Daily intake }(\mathrm{g}) \text { : } \\
\text { - dry matter } \\
\text { - digestible organic matter } \\
\text { - digestible crude protein }\end{array}$ & $\begin{array}{r}928 \\
742 \\
90\end{array}$ & $\begin{array}{l}733\left(^{a}\right) \\
569\left(^{a}\right) \\
58\left(^{a}\right)\end{array}$ & $\begin{array}{l}1079\left({ }^{b}\right) \\
858(\mathrm{~b}) \\
105(\mathrm{~b})\end{array}$ & $\begin{array}{l}1020\left(^{b}\right) \\
807\left({ }^{b}\right) \\
81\left(^{a}\right)\left(^{b}\right)\end{array}$ & 11.9 \\
\hline
\end{tabular}

(a) : Significantly different $(P \leqslant 0.05)$ from the controls. (b) : Significantly different $(P \leqslant 0.05)$ from the 11.5-week old animals. 
are identical (Horino et al., 1968) and, the injected hormone was identical to the native hormone in other respects since the former was unlabelled. The injection of strong doses of insulin has the disadvantage of causing peripheral blood insulin to rise well above physiological levels. These high levels of insulin had three effects. First, they reduced endogenous insulin secretion (Dunbar et al., 1976 ; Schatz and Pfeiffer, 1977) and therefore the rate of the disappearance of insulin from the circulation was overestimated. Secondly, the high levels reduced hepatic insulin extraction (Tranberg and Dencker, 1978; Harding, Bloom and Field, 1975 ; Mondon et al., 1975 ; Sonksen et al., 1973 ; Tiran, Avruch and Albisser, 1979 ; Honey and Price, 1979 ; Misbin, Mérimée and Lowenstein, 1976) and thirdly, they resulted in a decrease in blood glucose that is known to increase the metabolic clearance rate of insulin and the secretion of hyperglycaemic hormones (Brockman and Bergman, 1975). However, the insulin injections had no apparent effects on animal behaviour.

Chemical analysis. - Using a commercial kit available from CEA-IRESORIN, France, immunoreactive plasma insulin was measured by radioimmunoassay based on the double-antibody method (Yalow and Berson, 1960 ; Morgan and Lazarow, 1963). Human insulin was used as a standard. Because porcine and human insulin are immunologically similar (Hales and Randle, 1963), human insulin was a valid standard for radioimmunoassay of the injected porcine hormone. In contrast, human insulin differs from ovine insulin (Trenkle, 1972). Therefore, ovine immunoreactive insulin in plasma might have been slightly underestimated since insulin antibodies could have a lower affinity for ovine than for human insulin. Whole-blood glucose was determined by an automatic procedure using glucose-oxidase. Free amino acids were extracted from whole blood with cold ethanol at $82 \%$ and estimated by ion-exchange column chromatography on an automatic apparatus (Moore, Spackman and Stein, 1958).

Analysis of data. - In all calculations of the disappearance of injected insulin, the insulin level before insulin injection was subtracted from the total insulin level (endogenous insulin release was assumed to remain constant). Individual disappearance curves were divided into two parts; the first part included up to $7 \mathrm{~min}$ after injection and the second part from 15 to $60 \mathrm{~min}$ after injection. The kinetic parameters of insulin metabolism were computed according to Trenkle (1971) and Pilo, Navalesi and Ferrannini (1976) on the second part of the disappearance curve. The first part of the curve was not considered in the calculations since its significance in insulin metabolism was not clear. The fractional turnover rate $(K)$ was the slope of the linear regression of the plasma insulin level logarithm vs time after insulin injection. The regression line was extrapolated to zero time to obtain the theoretical level of plasma insulin at time zero (C) after the exogenous insulin was completely distributed in the insulin pool, but before any had been lost. Half-life $\left(T_{1 / 2}\right)$ was obtained from the formula : $T_{1 / 2}=0.693 / \mathrm{K}$. Initial distribution volume (IDV) was obtained from the formula : IDV = (exogenous insulin injected) $/ \mathrm{C}$. Metabolic clearance rate (MCR) was estimated as follows: $M C R=K \times$ IDV. Insulin secretion rate (S) was assumed to equal insulin disappearance rate. The latter was computed from the 
equation : $\mathrm{S}=$ MCR $\times$ (basal plasma insulin level). MCR was assumed to be constant over the day since it was not modified after feeding (Trenkle, 1971). Basal plasma insulin level was obtained throughout the day. Linear unweighted regressions were used. The groups were compared by variance analysis and covariance analysis (Snedecor and Cochran, 1971).

\section{Results.}

Immunoreactive plasma insulin throughout the day. - Throughout the day (except at 3 p.m.), the mean plasma insulin level increased significantly $(P<$ 0.050 ) with BW logarithm in a similar manner in both groups. The equation of the regression line (not shown) and the correlation coefficient, where $y$ and $x$ were the ordinate and the abscissa, respectively, were $y=1.34 x-9.392$; $r=0.57$ for the control group and $y=1.38 x-2.041 ; r=0.63$ for the experimental group. In the control group, daily gain was similar at both BW's; in the experimental group, it was higher at $33-\mathrm{kg} \mathrm{BW}$ than at $23-\mathrm{kg} \mathrm{BW}$ (table 3).

At 23-kg BW in the control group, plasma insulin showed an increase at 10 a.m. (fig. 1a), then remained constant for the rest of the day. In the experimental group, plasma insulin exhibited an important peak at $3 \mathrm{p.m}$. and a small increase over the dark period. At 23-kg BW in both groups, variations in

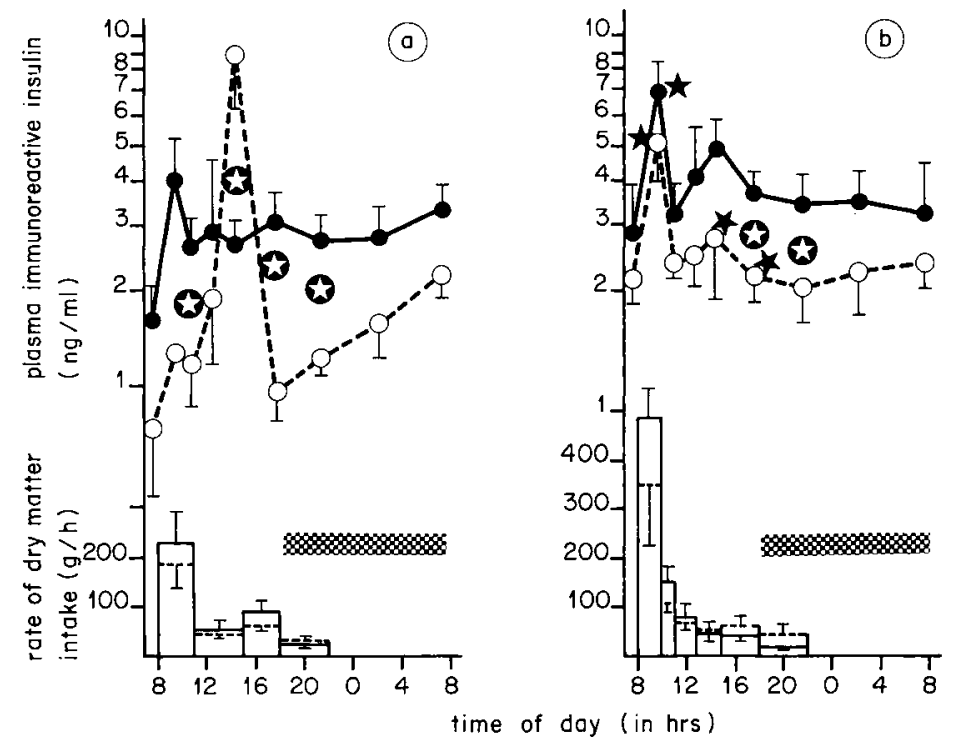

FIG. 1. - Daily variations in immunoreactive plasma insulin and rate of dry matter intake throughout the day in the control (@) and experimental $(0----0)$ groups : (a) at $23 \mathrm{~kg}$ of liveweight ; (b) at $33 \mathrm{~kg}$ of liveweight. Dark areas are the dark periods. Each point is the mean $\pm \mathrm{SE}(\mathrm{n}=5$ or 6 ). $\$$ : experimental group values were significantly different $(P<0.05)$ from the corresponding values of the control group. $\psi$ : values observed at $33 \mathrm{~kg}$ of liveweight were significantly different $(P<0.05)$ from the corresponding values observed at $23 \mathrm{~kg}$ of liveweight in the same group. 
TABLE 3

Daily gain, blood glucose and blood free amino-acids

\begin{tabular}{|c|c|c|c|c|c|}
\hline \multirow{2}{*}{ Group } & \multicolumn{2}{|c|}{ First period } & \multicolumn{2}{|c|}{ Second period } & \multirow{2}{*}{$\begin{array}{l}\text { Mean coeffi- } \\
\text { cient of varia- } \\
\text { tion }(\%)\end{array}$} \\
\hline & Control & Experimental & Control & Experimental & \\
\hline Daily gain $\langle\mathbf{g}\rangle$ & 272 & $207\left({ }^{a}\right)$ & 281 & $303\left(^{b}\right)$ & 20.6 \\
\hline $\begin{array}{l}\text { Blood glucose (mg/100 g } \\
\text { whole blood) (1) }\end{array}$ & 62 & $50\left({ }^{a}\right)$ & $54\left({ }^{b}\right)$ & 56 & 8.4 \\
\hline $\begin{array}{l}\text { Free amino acids (mg/100 g } \\
\text { whole blood) (1) }\end{array}$ & & & & & \\
\hline $\begin{array}{l}\text { - Essential + tyrosine } \\
\text { - Non-essential }\end{array}$ & $\begin{array}{l}14.0 \\
15.9\end{array}$ & $\begin{array}{l}10.8\left(^{\mathrm{a}}\right) \\
14.5\end{array}$ & $\begin{array}{l}13.6 \\
14.2\end{array}$ & $\begin{array}{l}13.7 \text { (b) } \\
14.6\end{array}$ & $\begin{array}{l}7.8 \\
9.0\end{array}$ \\
\hline
\end{tabular}

(a) : Significantly different $(P \leqslant 0.05)$ from the controls. (b) : Significantly different $(P \leqslant 0.05)$ from 11.5-week old animals. (1): Mean value over the day.

plasma insulin between 8 a.m. and 10 a.m. were positively related $10.02<P<$ 0.05) to the rate of dry matter intake. At 33-kg BW (fig. 1b), the trend of changes in plasma insulin with time were not different between the control and the experimental sheep. Plasma insulin showed a peak at $10 \mathrm{a} . \mathrm{m}$. that was not significantly related to the rate of dry matter intake. In addition, it showed an increase at $3 \mathrm{p} . \mathrm{m}$. At $23-\mathrm{kg}$ BW in both groups, dark period insulin values were higher than prefeeding values (fig. 1a); at 33-kg BW, they were constant and similar to prefeeding values (fig. 1b). Blood glucose and blood free amino acids did not change with the time of day in either group (not shown).

During each sampling day (except at 3 p.m.), the mean immunoreactive plasma insulin level was significantly lower $(0.005<P<0.010)$ in the experimental than in tha control group (fig. 1a and b). Surprisingly, the plasma insulin level just before insulin injection was the same in both groups (table 4). This discrepancy was due to variations in the time of injection and to daily variations in plasma insulin. At $23-\mathrm{kg}$ BW, daily gain, blood glucose and essential blood free amino acids were lower in experimental animals than in controls. In contrast at 33-kg BW, they were similar in both groups (table 3).

Disappearance of injected insulin from the circulation. - In the 1-hour period after injection, the insulin level decreased from approximately 60 times its basal level to about 8 times its basal level (fig. 2). The disappearance rate was about two times faster for the first part of the disappearance curve (up to $7 \mathrm{~min}$ after injection) than for the second part of the curve (15-60 min after injection). Two hours after injection, insulin concentration neared basal level (5.3 \pm $0.7 \mathrm{ng} / \mathrm{ml} ; \pm \mathrm{SE})$.

In both groups, plasma insulin along the disappearance curve was significantly higher at 33-kg BW than at 23-kg BW (fig. 2). This correlated with significant increases in the amount of injected insulin (table 4). In addition, calculation showed that the metabolic clearance rate of insulin was significantly reduced. The initial distribution volume per $\mathrm{kg}$ of liveweight decreased with increasing $\mathrm{BW}$; this correlation was significant in experimental animals but not 


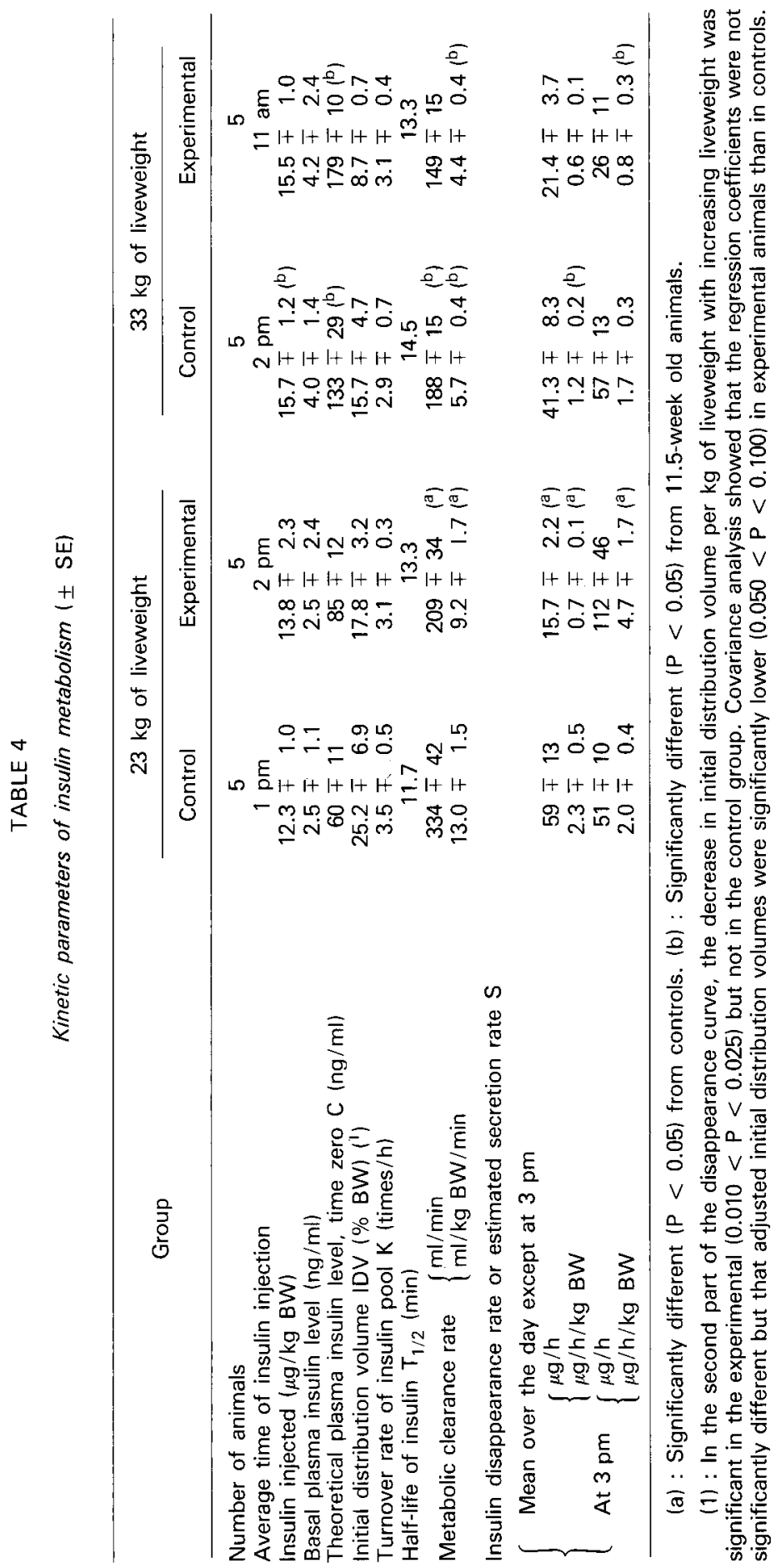


in controls (regressions not shown). The turnover rate of the insulin pool and insulin half-life were unchanged.

Plasma insulin concentration was slightly higher in the experimental than in the control sheep for the second part of the disappearance curve (significant at 15 and $30 \mathrm{~min}$ after injection at 33-kg BW) (fig. 2). Calculation showed that when the experimental diet was given, there was a small increase in the theoretical plasma insulin level at time zero, due to a decrease in the volume of initial insulin distribution (table 4). The turnover rate of the insulin pool and insulin half-life were not significantly modified. At $23-\mathrm{kg} \mathrm{BW}$, the metabolic clearance rate of insulin was significantly lower in the experimental than in the control group; at $33-\mathrm{kg} \mathrm{BW}$, it was similar in both groups.

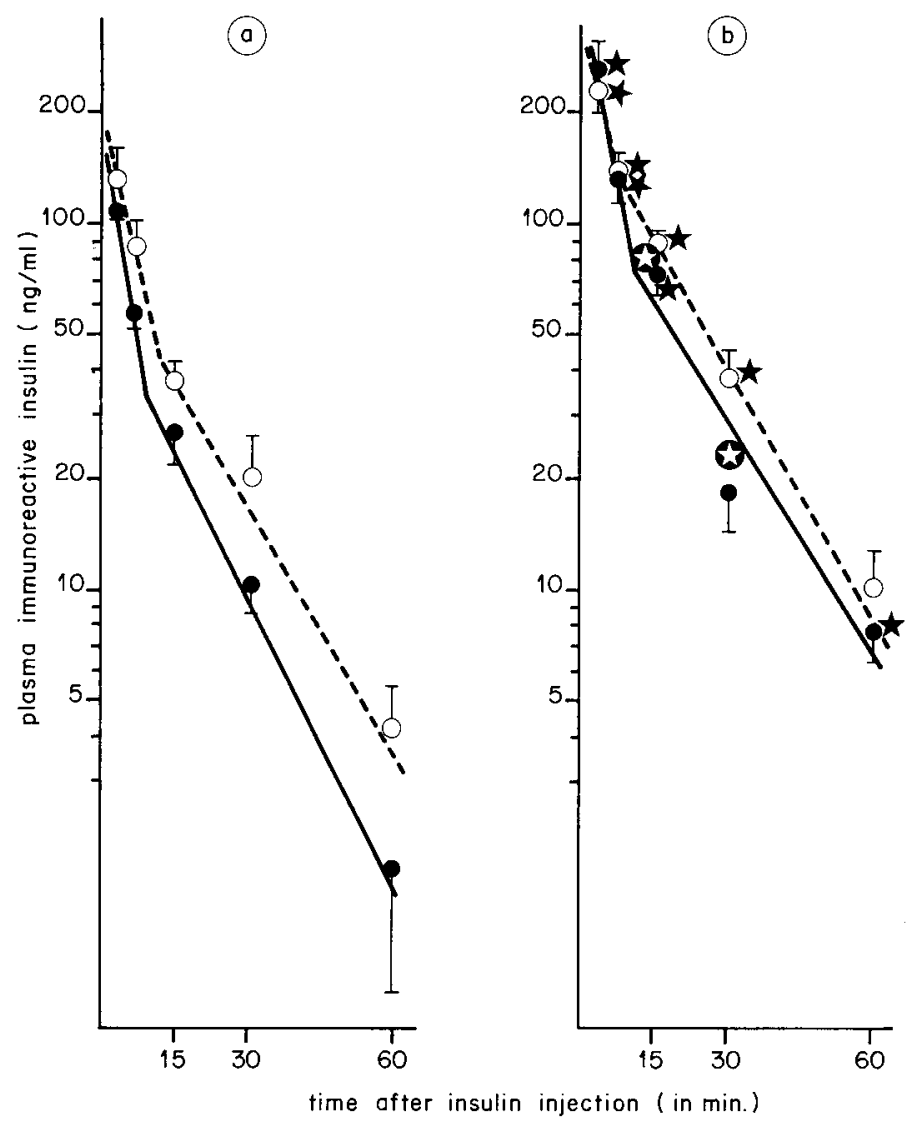

FIG. 2. - Disappearance curves of injected insulin in the control ( , - $)$ and experimental $10,-----)$ group : (a) at $23 \mathrm{~kg}$ of liveweight; (b) at $33 \mathrm{~kg}$ of liveweight. Basal insulin level was subtracted from the measured insulin level. Each point is the mean $\pm \mathrm{SE}(\mathrm{n}=5$ or 6 ). Computed lines fitted linear regressions up to $7 \mathrm{~min}$ after injection and $15-60 \mathrm{~min}$ after injection, respectively. $\boldsymbol{\Theta}$ : experimental group values were significantly different $(P<0.05)$ from the corresponding values of the control group. $\psi$ : values observed at $33 \mathrm{~kg}$ of liveweight were significantly different $(P<0.05)$ from the corresponding values observed at $23 \mathrm{~kg}$ of liveweight in the same group. 
Estimated insulin secretion. - Except at 3 p.m. the average insulin secretion rate per unit of $\mathrm{BW}$ in the control group was significantly lower throughout the day at $33-\mathrm{kg} \mathrm{BW}$ than at $23-\mathrm{kg} \mathrm{BW}$ (table 4); in the experimental group it was similar at both BW's.

Except at 3 p.m. on the first sampling day, the average insulin secretion rate over each sampling day was lower in the experimental than in the control group ; in contrast, at 3 p.m. on the first sampling day, that rate was significantly higher in the experimental than in the control group.

\section{Discussion.}

Insulin metabolism in sheep. - The curve of exogenous insulin disappearance from the circulation was similar to results on several non-ruminant species (Tranberg and Dencker, 1978; Sonksen et al., 1973; Wirth et al., 1980 ; Palumbo et al., 1972; Sherwin et al., 1974). The significance of the first part of the curve is not clear. The initial distribution volume calculated from the second part of the disappearance curve probably involved extracellular fluid volume and the receptor compartment (Zeleznik and Roth, 1978). The metabolic clearance rate of insulin $(4-13 \mathrm{ml} / \mathrm{min} / \mathrm{kg}$ of $\mathrm{BW})$ was slightly lower than that observed in non-ruminants (Tranberg and Dencker, 1978; Navalesi, Pilo and Ferrannini, 1976 ; Sonksen et al., 1973 ; Katz and Rubenstein, 1973). The difference was undoubtedly greater than noted because the metabolic clearance rate of insulin has been underestimated in most cited publications due to the fact that it was measured using a labelled hormone (Genuth, 1972). The low metabolic clearance rate of insulin in sheep, compared to other species, could result from lower liver insulin clearance (Brockman and Bergman, 1975).

Plasma insulin level showed a peak $2 \mathrm{~h}$ after feeding and an increase $7 \mathrm{~h}$ after feeding. A similar trend of changes in plasma insulin with time after feeding has been noted in ruminants (Trenkle, 1978; Chase, Wangness and Martin, 1977). If we assume that the metabolic clearance rate was unchanged (Trenkle, 1971), insulin secretion increased after feeding. This could not be attributed to increases in $\beta$ cell stimuli by glucose and amino acids. Indeed, the blood levels of these metabolites did not change with the time of day since the processes of digestion and absorption in ruminants are prolonged. Alternatively, unmeasured $\beta$ cell stimuli such as volatile fatty acids, intestinal hormones and neurological stimulation could be involved in the postprandial regulation of insulin secretion (Bassett, 1975).

Effect of age or liveweight. - The increase in immunoreactive plasma insulin with BW is similar to the increased blood insulin level observed in cattle during the finishing period (Irvin and Trenkle, 1971; Trenkle and Topel, 1978) and in growing sheep (John and Bergen, 1976). This result could not be explained by an increase in insulin secretion since the insulin secretion rate per unit of BW was decreased (control group) or unchanged (experimental group). It could be explained by the decrease in the metabolic clearance rate of insulin. This decrease could result from a drop in extracellular fluid volume or it might be due to a reduction in cellular insulin losses since insulin receptor binding and the 
potency of insulin degradation in the cells decrease with increasing BW in growing rats (Freeman, Karoly and Adelman, 1973; Kelly et al., 1974; Olefsky and Reaven, 1975 ; Runyan et al., 1979). In the present study, blood insulin had not returned to prefeeding levels after $24 \mathrm{~h}$ in either group at $23-\mathrm{kg} \mathrm{BW}$. In the young animals, this could be due to handling stress associated with sampling.

\section{Effect of the experimental diet.}

- At 23-kg BW. Feeding the experimental diet resulted in a decrease in plasma insulin level at all times of the day, except at 3 p.m. Calculation showed that insulin secretion was strongly reduced at $23-\mathrm{kg}$ BW. This decrease was probably caused by a drop in blood glucose and blood essential free amino acids (see table 3) since glucose and some essential amino acids are known to be potent stimuli of $\beta$ cells in ruminants (Bassett, 1975; Trenkle, 1978; Davis, 1972 ; Oldham, Hart and Bines, 1978). Alternatively, insulin response to $\beta$ cell stimuli could have been decreased (Atinmo et al., 1978; Turner and Bryant, 1976). This decrease, correlated with the reduction in blood insulin level found with reduced intake of dietary crude protein in ruminants (Martin et al., 1979 ; Borger et al., 1973 ; John and Bergen, 1976) and non-ruminants (Edozien et al., 1978; Kabadi, Eisenstein and Strack, 1976), could also be caused by the energy restriction accompanying nitrogen restriction because the former is known to lower plasma insulin level (Grizard et al., 1979). In contrast, feeding the experimental diet at 3 p.m. resulted in an increase in plasma insulin. This is probably due to an increase in insulin secretion under the effect of propionic acid used as a feed additive. An increase in blood insulin level has been observed previously in sheep following propionic acid injection into the rumen in equivalent quantities (Weekes, 1975).

Feeding the experimental diet resulted in a strong decrease in the metabolic clearance rate of insulin. This result contrasts with the constant metabolic clearance rate of insulin found in fasted sheep (Trenkle, 1971) or in foodrestricted rats (Wirth et al., 1980). It also contrasts with the constant rate of hepatic removal of insulin by the liver in fasted rats (Misbin, Mérimée and Lowenstein, 1976) or in rats fed low-protein diets (Sacks et al., 1977).

- At 33-kg BW. Feeding the experimental diet decreased blood insulin in a similar manner at $33-\mathrm{kg} \mathrm{BW}$ and at $23-\mathrm{kg}$ BW. However, compared to $23-\mathrm{kg}$ BW, blood insulin did not increase at 3 p.m. at $33-\mathrm{kg} \mathrm{BW}$. Furthermore, insulin secretion and the metabolic clearance rate of insulin showed no significant decrease. These results correlate with less severe nitrogen restriction and constant blood levels of $\beta$ cell stimuli (i.e. glucose and essential free amino acids) (see table 3 ). The level of propionic acid in the diet might have also decreased with feed storage. These results cannot be attributed to an increment in age from controls to experimental animals (18 vs 15.5 weeks). Indeed, increasing BW (or age) in the controls resulted in a decrease in insulin secretion and in the insulin metabolic clearance rate (see above).

Reçu en mai 1982.

Accepté en novembre 1982. 
Acknowledgements. - The authors wish to thank Dr. G. Rosselin and Dr. B. Desbuquois for their comments on the manuscript. They also wish to thank Mrs. Francoise Barre for her technical assistance, Mr. Theriez for the animals and the diet supply and A. Selle and $M$. Sallas for help in obtaining the sheep.

Résumé. Métabolisme de l'insuline chez l'agneau ruminant en croissance. Influence de l'âge et du régime.

Le présent travail a pour but d'étudier le métabolisme de l'insuline chez l'agneau ruminant en croissance recevant soit un régime témoin soit un régime expérimental (pauvre en matières azotées aussi bien que riche en acide propionique). Les variations nycthémérales de l'insulinémie sont mesurées. La teneur plasmatique en insuline est également déterminée à différents temps après l'injection intraveineuse d'une forte dose d'insuline non radioactive, dans le but de calculer les taux de clairance métabolique et de sécrétion de l'hormone.

Au poids moyen de $23 \mathrm{~kg}$, l'insulinémie atteint une valeur maximale à $10 \mathrm{~h}$ le matin dans le lot témoin et à $3 \mathrm{~h}$ l'après-midi dans le lot expérimental. Dans les deux lots, au poids moyen de $33 \mathrm{~kg}$, elle présente un pic à $10 \mathrm{~h}$ le matin ainsi qu'une augmentation modérée à $3 \mathrm{~h}$ l'après-midi. Si le temps $3 \mathrm{~h}$ l'après-midi n'est pas pris en compte, l'insulinémie moyenne au cours du nycthémère augmente avec le poids corporel. Elle est significativement plus faible dans le lot expérimental que dans le lot témoin.

La période de demi-vie de l'insuline injectée est constante chez tous les animaux $(13 \mathrm{~min})$. Dans les deux lots, l'insulinémie constatée à différents temps après l'injection est plus forte au poids moyen de $33 \mathrm{~kg}$ qu'à celui de $23 \mathrm{~kg}$. Le taux de clairance métabolique de l'insuline est diminué. De plus, dans le lot témoin, la sécrétion d'insuline moyenne au cours du nycthémère (moins la valeur à $3 \mathrm{~h}$ l'après-midi) est abaissée. L'insulinémie constatée à différents temps après l'injection est plus forte dans le lot expérimental que dans le lot témoin. Au poids moyen de $23 \mathrm{~kg}$, le taux de clairance métabolique de l'hormone est diminué ; la sécrétion d'insuline est accrue à $3 \mathrm{~h}$ l'après-midi alors qu'elle est diminuée aux autres temps. Au poids moyen de $33 \mathrm{~kg}$, les paramètres calculés du métabolisme de l'insuline ne sont pas significativement modifiés.

\section{References}

ATINMO T., BALDIJAO C., HOUPT K. A., POND W. G., BARNES R. H., 1978. Plasma levels of growth hormone and insulin in protein malnourished $v$.s. normal growing pigs in response to arginine or glucose infusion. J. anim. Sci, 46, 409-416.

BASSETT J. M., 1975. Dietary and gastrointestinal control of hormones regulating carbohydrate metabolism in ruminants, 338-398. In Mc DONALD I. W., WARNER A. C. I., Digestion and metabolism in the ruminant. Univ., New England.

BORGER M. K., WILSON L. L., SINK J. D., ZIEGLER J. H., DAVIS S. L., 1973. Zeranol and dietary protein level effects on live performance, carcass merit, certain endocrine factors and blood metabolite levels of steers. J. anim. Sci., 36, 706-711.

BROCKMAN R. P., BERGMAN E. N., 1975. Quantitative aspects of insulin secretion and its hepatic and renal removal in sheep. Am. J. Physiol., 229, 1338-1343.

CHASE L. E., WANGNESS P. J., MARTIN R. J., 1977. Portal blood insulin and metabolite changes with spontaneous feeding in steers. J. Dairy Sci., 60, 410-415.

DAVIS S. L., 1972. Plasma levels of prolactin, growth hormone and insulin in sheep following the infusion of arginine, leucine and phenylalanine. Endocrinology, 91, 549-555.

DUNBAR J. C., Mic LAUGHLIN W. J., WALSH M. F. J., FOA P. P., 1976. Insulin secretion and glucose uptake by isolated islets of the hamster. Effect of insulin, proinsulin and C-peptide. Horm. metab. Res., 8, 1-6. 
EDOZIEN J. C., NIEHAUS N., MAR M. H., MAKOUI T., SWITZER B. R., 1978. Diet-hormone interrelationships in the rat. J. Nutr., 108, 1767-1776.

FREEMAN C., KAROLY K., ADELMAN R. C., 1973. Impairments of availability of insulin to liver in vivo and in binding to purified hepatic plasma membrane during aging. Biochem. biophys. Res. Communic., 54, 1573-1580.

GENUTH S. M., 1972. Metabolic clearance of insulin in man. Diabetes, 21, 1003-1012.

GRIZARD J., SZCZYGIEL M., 1980. Influence d'une restriction azotée sur le métabolisme de l'insuline et les récepteurs d'insuline dans le foie de l'agneau ruminant en croissance. Ann. Nutr. Alim., 34, 514.

GRIZARD J., TISSIER M., THERIEZ M., PION R., 1979. Variations de l'insulinémie chez la brebis en fin de gestation et début de lactation. Influence de l'état nutritionnel en fin de gestation. Ann. Biol. anim. Bioch. Biophys., 19, 73-78.

HALES C. N., RANDLE P. J., 1963. Immunoassay of insulin with insulin antibody precipitate. Biochem. J., 88, 137-146.

HARDING P. E., BLOOM G., FIELD J. B., 1975. Effect of infusion of insulin into portal vein on hepatic extraction of insulin in anaesthetized dogs. Am. J. Physiol., 228, 1580-1588.

HONEY R. N., PRICE S., 1979. The determinants of insulin extraction in the isolated perfused rat liver. Horm. metab. Res., 11, 111-117.

HORINO M., MACHLIN L. J., HERTELENDY F., KIPNIS D. M., 1968. Effect of short-chain fatty acids on plasma insulin in ruminant and non-ruminant species. Endocrinologv, 83, 118-128.

IRVIN R., TRENKLE A., 1971. Influence of age, breed and sex on plasma hormones in cattle. J. anim. Sci., 32, 292-295.

JARRIGE R., JOURNET M., VÉRITÉ R., 1978. Azote 89-128. In Alimentation des ruminants. INRA Publications, Ed., Route de Saint-Cyr, 78000 Versailles.

JOHN J. T., BERGEN W. G., 1976. Growth in sheep. pre and post-weaning hormone changes and muscle and liver development. J. anim. Sci., 43, 192-200.

KABADI U. M., EISENSTEIN A. B., STRACK 1., 1976. Decreased plasma insulin but normal glucagon in rats fed low protein diets. $J$. Nutr., 106, 1247-1253.

KATZ A. I., RUBENSTEIN A. H., 1973. Metabolism of proinsulin, insulin and C-peptide in the rat. J. clin. Invest., 52, 1113-1121.

KELLY P. A., POSNER B. I., TSUSHIMA T., FRIESEN H. G., 1974. Studies of insulin, growth hormone and prolactin binding : ontogenesis, effect of sex and pregnancy. Endocrinology, 95, 532-539.

MARTIN T. G., MOLLETT T. A., STEWART T. S., ERB R. E., MALVEN P. V., VEENHUISEN E. L., 1979. Comparison of four levels of protein supplementation with and without oral diethylstibestrol on blood plasma concentrations of testosterone, growth hormone and insulin in young bulls. J. anim. Sci, 49, 1489-1496.

MISBIN R. I., MERIMEE T. J., LOWENSTEIN J. M., 1976. Insulin removal by isolated perfused rat liver. Am. J. Physiol., 230, 171-177.

MONDON C. E., OLEFSKY J. M., DOLKAS C. B., REAVEN G. M., 1975. Removal of insulin by perfused rat liver : effect of concentration. Metabolism, 24, 153-160.

MOORE S., SPACKMAN D. H., STEIN W. H., 1958. Chromatography of aminoacids on sulfonated polystyrene resins. Analyt. Chem., 30, 1185-1190.

MORGAN C. R., LAZAROW A., 1963. Immunoassay of insulin : two-antibody system. Plasma insulin levels of normal, subdiabetic and diabetic rats. Diabetes, 12, 115-126.

NAVALESI R., PILO A., FERRANNINI E., 1976. Insulin kinetics after portal and peripheral injection of $\left({ }^{125}\right.$ ) insulin. II. Experiments in the intact dog. Am. J. Physiol., 230, 1630-1636.

OLDHAM J. D., HART I. C., BINES J. A., 1978. Effect of abomasal infusions of casein, arginine, methionine or phenylalanine on growth hormone, insulin, prolactin, thyroxine and some metabolites in blood from lactating goats. Proceed. Nutr. Soc., 37, 9 A.

OLEFSKY J. M., REAVEN G. M., 1975. Effects of age and obesity on insulin binding to isolated adipocytes. Endocrinology, 96, 1486-1498.

PALUMBO P. J., TAYLOR W. F., MOLNAR G. D., TAUXE W. N., 1972. Disappearance of bovine insulin from plasma in diabetic and normal subjects. Metabolism, 21, 787-798.

PILO A., NAVALESI R., FERRANNINI E., 1976. Insulin kinetics after portal and peripheral injection of $\left({ }^{125} \mathrm{I}\right)$ insulin. I. Data analysis and modelling. Am. J. Physiol., 230, 1626-1629. 
RUNYAN K., DUCKWORTH W. C., KITABCHI A. E., HUFF G., 1979. The effect of age on insulin degrading activity in rat tissue. Diabetes, 28, 324-325.

SACKS H., PIMSTONE B., WALIGORA K., PEIRES L., WEINKOVE E., SAUNDERS S., 1977. Differences between insulin degradation by soluble fractions and insulin clearance by perfused livers of normal, protein-depleted and starved rats. Diabetes, 26, 956-966.

SCHATZ H., PFEIFFER E. F., 1977. Release of immunoreactive and radioactively prelabelled endogenous (pro-) insulin from isolated islets of rat pancreas in the presence of exogenous insulin. J. Endocr., 74, 248-249.

SHERWIN R. S., KRAMER K. J., TOBIN J. D., INSEL P. A., LILJENOUIST J. E., BERMAN M., ANDRES R., 1974. A model of the kinetics of insulin in man. J. clin. Invest., 53, $1481-1492$.

SNEDECOR G. W., COCHRAN W. G., 1971. Méthodes statistiques, A.C.T.A., Paris.

SONKSEN P. H., TOMPKINS C. V., SRIVASTAVA M. C., NABARRO J. D. N., 1973. A comparative study on the metabolism of human insulin and porcine proinsulin in man. Clin. Sci. mol., Med., 45, 633-654.

TIRAN J., AVRUCH L. I., ALBISSER A. M., 1979. A circulation and organ model for insulin dynamics. Am. J. Physiol., 237, E 331-E 339.

TRANBERG K. G., DENCKER H., 1978. Modelling of plasma disappearance of unlabelled insulin in man. Am. J. Physiol., 235, E 577-E 585.

TRENKLE A., 1971. Postprandial changes in insulin secretion rates in sheep. J. Nutr., 101, 10991103.

TRENKLE A., 1972. Radioimmunoassay of plasma hormones : review of plasma insulin in ruminants. J. Dairy Sci., 55, 1200-1210.

TRENKLE A., 1978. Relation of hormonal variations to nutritional studies and metabolism in ruminants. J. Dairy Sci., 61, 281-293.

TRENKLE A., TOPEL D. G., 1978. Relationships of some endocrine measurements to growth and carcass composition of cattle. J. anim. Sci., 46, 1604-1609.

TURNER M. R., BRYANT J. S., 1976. Insulin secretion in young and adult offspring of rats given diets of varying protein and sucrose content during pregnancy and lactation. Proceed. Nutr. Soc., 35, $122 \mathrm{~A}$.

WEEKES T. E. C., 1975. Effects of infusion of volatile fatty acids into the rumen on insulin release in sheep. J. Physiol., 254, $80 \mathrm{P}$.

WIRTH A., HOLM G., NILSON B., SMITH U., BJÖRNTORP P., 1980. Insulin kinetics and insulin binding to adipocytes in physically trained and food-restricted rats. Am. J. Physiol., 238, E 108-E 115.

YALOW R. S., BERSON S. A., 1960. Immunoassay of endogenous plasma insulin in man. $J$. Clin. Invest., 39, 1157-1175.

ZELEZNIK A. J., ROTH J., 1978. Demonstration of the insulin receptor in vivo in rabbits and its possible role as a reservoir for the plasma hormone. J. Clin. Invest., 61, 1363-1374. 